\title{
The Narratives of Cyberspace Law (or, Learning From Casablanca)
}

\author{
Michael J. Madison*
}

\section{INTRODUCTION}

The number of legal and other social issues created or affected by computer networks and our use of computer technology appears overwhelmingly diverse. In law, these issues have been collected and analyzed as a "law of the internet" or "law of cyberspace." Critics have objected that neither the artifact of the internet nor the experience we call cyberspace ${ }^{2}$ justifies unifying perspectives on such topics as copyright law, defamation, taxation, contract formation, unreasonable searches and personal jurisdiction. ${ }^{3}$ Despite the criticism, lawyers, legal scholars and even judges intuit that something having to do with modern computing technology must connect the changes now observed in each of these fields. Both popular and technical understanding refer to "the internet" and to "cyberspace" as

* Assistant Professor, University of Pittsburgh School of Law. Email: madison@law.pitt.edu. My thanks to Michael Froomkin, whose use of the phrase "papers, please" in a talk on privacy technologies unintentionally inspired this paper, and to George Taylor, Fred Yen, Martha Woodmansee and Aviam Soifer for thoughtful comments and criticism.

1. Crystallization of these fields is evident in the flourishing market for relevant law school casebooks. See, e.g., Patricia L. Bellia et al., Cyberlaw: Problems of Policy and JuRisprudENCE IN THE INFORMATION Age (2003); RAYMOND S. R. Ku ET AL., Cyberspace LAW:

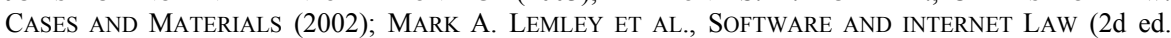
2003); Peter B. Maggs, InTERnet And Computer LaW: CASES - COMMENTS-Questions (2001); LAWRENCE LESSIG ET AL., INTERNET LAW (forthcoming 2004).

2. "The internet" being the collective term for the hardware and software technology that underlies interconnected computer networks and "cyberspace" being the collective term for human experiences of engaging with a computer-mediated, network environment. See Brett M. Frischmann, Reconciling Internet and Cyberspace, 35 LOY. U. CHI. L.J. (forthcoming 2004) (arguing that the two phenomena ought to be separated for legal analysis); Orin S. Kerr, The Problem of Perspective in Internet Law, 91 GEO. L.J. 357 (2003) (arguing that given legal problems involving online behavior can be analyzed from either perspective). In popular culture, these terms are often used interchangeably. As the technology of the internet becomes ever more invisible, where the "technology" leaves off and the "experience" begins is difficult to determine. I use the term "cyberspace" for this Article, but I do not draw a hard and fast distinction between the two terms. But cf. Reno v. ACLU, 521 U.S. 844, 851 (1997) ("Taken together, these tools [e-mail, newsgroups, the World Wide Web, etc.] constitute a unique medium - known to its users as 'cyberspace'-located in no particular geographical location but available to anyone, anywhere in the world, with access to the internet.").

3. See, e.g., Joseph H. Sommer, Against Cyberlaw, 15 Berkeley TeCH. L.J. 1145, 1150-51 (2000). Sommer nonetheless makes his argument in the form of "stories" about the internet and legal questions related to it. 
unitary phenomena, knowing full well that there is no such single thing beneath either label. ${ }^{4}$ Surely this understanding, and not simply the scholar's instinct to abstract and generalize, has produced the persistence of debates over the right answer to the question: what is cyberspace? The range of answers to date includes the propositions that cyberspace (or the internet) is or is not analogous to one or more of a host of mostly physicalized constructs. Cyberspace is "a single body of knowledge. ${ }^{5}$ Cyberspace is a place, ${ }^{6}$ a collection of places, ${ }^{7}$ a network, ${ }^{8}$ a highway 9 and an information "commons. ${ }^{10}$ It is a marketplace, ${ }^{11}$ an open space, ${ }^{12}$

4. See Philip E. Agre, Cyberspace as American Culture, 11 SCI. AS Culture 171, 174 (2002) ("The ideology of cyberspace ... is spectacularly wrong; yet facts do not seem to refute it."); Philip E. Agre, Yesterday's Tomorrow, Times LiteraRY SupPlement, July 3, 1998, at 3-4 (arguing that "cyberspace" is an artifact of the evolutionary interaction between network computing technology and the institutions and relationships into which it is being integrated). Information professionals have largely mastered this understanding. See, e.g., Christine L. Borgman, From Gutenberg to the GLOBAL INFORMATION INFRASTRUCTURE: ACCESS TO INFORMATION IN THE NETWORKED WORLD (2000) (analyzing libraries as a set of information practices that may include networked technology). But their insights have penetrated popular consciousness - and law-only to a limited extent. See, e.g., Kerr, supra note 2, at 357 (developing the argument that legal analysis regarding computer networks might take an "internal" or "external" perspective regarding the experience of the network).

5. ACLU v. Reno, 929 F. Supp. 824, 836-37 (E.D. Pa. 1996), aff'd, 521 U.S. 844 (1997). Cf. Margaret Jane Radin, Online Standardization and the Integration of Text and Machine, 70 FORDHAM L. REV. 1125, 1139-45 (2002) (noting that the blurring of text and machine in the digital world leads to an erosion of distinctions between legal standards and technical standards); WILLIAM J. MiTCHELL, CitY of Bits: SPACE, Place, AND THE INFOBAHN 65 (1995) (describing online blurring of traditional distinctions between performer and audience).

6. See Dan Hunter, Cyberspace as Place and the Tragedy of the Digital Anticommons, 91 CAL. L. REV. 439 (2003); eBay, Inc. v. Bidder's Edge, Inc., 100 F. Supp. 2d 1058, 1070 (N.D. Cal. 2000) (granting preliminary injunction against auction aggregator service that committed "trespass" to the plaintiff's auction website, where interference with plaintiff's property interest consisted of unauthorized access to plaintiff's computer servers).

7. See James Boyle, A Politics of Intellectual Property: Environmentalism for the Net?, 47 DUKE L.J. 87, 108-112 (1997); James Boyle, The Second Enclosure Movement and the Construction of the Public Domain, LAW \& ConTEMP. ProBs., Winter/Spring 2003, at 33; Mark A. Lemley, Place and Cyberspace, 91 CAL. L. REv. 521 (2003); Lawrence Lessig, Reading the Constitution in Cyberspace, 45 EMORY L.J. 869, 883-95 (1996) (observing that the internet is capable of and is in fact being "zoned").

8. See Yochai Benkler, From Consumers to Users: Shifting the Deeper Structures of Regulation Toward Sustainable Commons and User Access, 52 FED. COMM. L.J. 561, 562-63 (2000) (describing internet as a series of network layers); I. Trotter Hardy, Computer RAM "Copies": A Hit or a Myth? Historical Perspectives on Caching as a Microcosm of Current Copyright Concerns, 22 U. DAYTON L. REV. 423, 436-37 (1997).

9. See Jane C. Ginsburg, Putting Cars on the "Information Superhighway": Authors, Exploiters, and Copyright in Cyberspace, 95 CoLuM. L. REv. 1466, 1466-68 (1995); Brookfield Communications, Inc. v. West Coast Entm't Corp., 174 F.3d 1036, 1062-64 (9th Cir. 1999) (explaining doctrine of "initial interest confusion" on the internet by analogy to billboard confusion on an interstate highway).

10. See Lawrence Lessig, The Future of Ideas: The fate of the Commons in a CONNECTED WORLD 23-26 (2001); Lawrence Lessig, Commons and Code, 9 Fordham InTELl. Prop. MEDIA \& ENT. L.J. 405, 405-12 (1999).

11. See Matt Jackson, One Step Forward, Two Steps Back: An Historical Analysis of Copyright Liability, 20 CARDOZO ARTS \& ENT. L.J. 367, 414 (2002); Larry E. Ribstein \& Bruce H. Kobayashi, State Regulation of Electronic Commerce, 51 EMORY L.J. 1, 19-23 (2002).

12. See Tom W. Bell, Book Review, 28 J. MAR. L. \& COM. 185, 186 (1997) (reviewing Henry H. Perritt, JR., LAW AND THE INFORMation SuPERhighway (1996)) (comparing the internet to the ocean). 
a "frontier,"13 a virtual community (or set of communities) ${ }^{14}$ and a set of medieval status-based relationships. ${ }^{15}$ Cyberspace has been characterized as a giant photocopier, ${ }^{16}$ as a book ${ }^{17}$ and as a library. ${ }^{18}$ "Cyberspace" itself is a metaphor, of course ${ }^{19}$ in part the exercise has been to tie one metaphor (place, for example) to another (cyberspace) in order to define an artifact (the internet).

But cyberspace is not any one of these things, though the effort to find a worthy metaphorical counterpart to this strange new technology and experience is an appropriate one. The metaphorical inquiry is inevitable, and it is necessary: The alleged artifact itself almost defies stable description on technical terms alone. ${ }^{20}$ Neither the internet nor cyberspace is a "thing" capable of re-conceptualization merely in terms of another "thing." The challenge is to conceptualize cyberspace for legal purposes, in a way that accommodates - if not resolves - the myriad of technologies, theories and practices to which cyberspace connects, and to do so in a way that is both comprehensible in contemporary terms and allows for evolution and adaptation in the future.

I propose instead to characterize cyberspace (or, if one prefers, the internet) as a story, a narrative. I do so both to echo its dynamic character and, more provocatively, to suggest that cyberspace has a plot, or perhaps multiple plots; that these plots have characters who interact with one another through some structure; that there are themes and motifs; that there are "good" characters, "bad" characters, winners and losers; and that eventually (though not necessarily simultaneously),

13. The canonical expression of this metaphor comes from Mitchell Kapor and John Perry Barlow, in their 1990 essay, Across the Electronic Frontier, at http://www.eff.org//Misc/Publications/ Mitch Kapor/electronic frontier.eff (July 10, 1990).

14. See Howard RHeingold, The Virtual Community: Homesteading on the Electronic FRONTIER (1993).

15. See Alfred C. Yen, Western Frontier or Feudal Society?: Metaphors and Perceptions of Cyberspace, 17 BERKELEY TECH. L.J. 1207, 1232-48 (2002).

16. See Religious Tech. Ctr. v. Netcom On-Line Communication Servs., Inc., 907 F. Supp. 1361, 1369 (N.D. Cal. 1995).

17. See generally Ann Bartow, Electrifying Copyright Norms and Making Cyberspace More Like a Book, 48 VILL. L. REV. 13 (2003).

18. See Mainstream Loudoun v. Bd. of Trs. of Loudoun County Library, 2 F. Supp. 2d 783, 79394 (E.D. Va. 1998) (rejecting library characterization in favor of "internet-as-encyclopedia"). Cf. New York Times Co. v. Tasini, 533 U.S. 483, 502-04 (2001) (comparing databases to libraries). At this point, the metaphorical journey has come full circle to Borges. See JoRge LuIS Borges, The Library of Babel, in LABYRINTHS: Selected StORIES \& OTHER Writings 51, 51 (Donald A. Yates \& James E. Irby eds., 1964). In the present spirit, this collection of metaphors might be referred to as "the usual suspects" after Captain Renault's famous line at the end of Casablanca: "Major Strasser has been shot. Round up the usual suspects." CASABLANCA (Warner Brothers Pictures 1942). Early predictions that existing metaphorical frameworks would prove inadequate for cyberspace have proved clearly wrong. See David R. Johnson \& Kevin A. Marks, Mapping Electronic Data Communications onto Existing Legal Metaphors: Should We Let Our Conscience (and Our Contracts) Be Our Guide?, 38 VILL. L. REV. 487, 514-15 (1993).

19. The novelist William Gibson famously characterized his fictional "cyberspace" as a “consensual hallucination." WiLliam GiBSON, NeUROMANCER 51 (1984).

20. See Agre, Cyberspace as American Culture, supra note 4, at 182-83 (describing how computing theory has failed to evolve in step with the embedding of networked technology beyond computing devices themselves). 
these plots may wind to a conclusion and new plots may begin. In the best of these senses, cyberspace, for now, is a thoroughly conventional popular narrative melodrama. In an earlier era, I might have characterized it as a work of literary fiction. $^{21}$ Today, connecting the suggestion to popular understanding means invoking a more contemporary literary form - the motion picture. ${ }^{22}$ If the narrative construct fits, others may search for their own celluloid analogs. The more stories and counterstories, the better. ${ }^{23}$ For now, and below, I argue that cyberspace is the electronic equivalent of the very best melodramatic, story-based narrative film ever made. ${ }^{24}$ Cyberspace is Casablanca. ${ }^{25}$

\section{FADE IN: CYBERSPACE-AS-NARRATIVE}

Enough with the metaphors, one might say, ${ }^{26}$ before I venture into stories and

21. Within literature, I am thoroughly anticipated by Jorge Luis Borges. See Borges, supra note 18 , at 51 ("The universe (which others call the Library) is composed of an indefinite and perhaps infinite number of hexagonal galleries, with vast air shafts between, surrounded by very low railings."). The infinite scale of the Library permits it to accommodate all words ever written and still yet to be written, so that hope at the availability of all knowledge collapses into despair at the impossibility of cataloguing it.

22. To be thoroughly contemporary, I could characterize cyberspace as a single computer game being played out on an unprecedented scale. But my argument would fail on the ground that it might be literally true. See, e.g., David Becker, "EverQuest" Spins Its Own Economy, at http://news.com.com/2100-1040-823260.html?tag=bplst (describing an international economy built by participants in online multi-character interactive computer game); F. Gregory Lastowka \& Dan Hunter, The Laws of the Virtual Worlds, CAL. L. REV. (forthcoming) (describing legal problems emanating from massive multi-player online games).

23. See Richard Delgado, Storytelling for Oppositionists and Others: A Plea for Narrative, 87 MicH. L. REV. 2411, 2439-40 (1989).

24. In 1998, a large panel of critics and other film industry participants convened by the American Film Institute listed the 100 greatest films ever made. Citizen Kane, Orson Welles's artistic tour de force of the moviemaker's art, was ranked first. Casablanca, competently produced but with no artistic ambitions, finished second. The rankings are available at American Film Institute's "AFI's 100 Years ... 100 Movies," at http://www.afi.com/tv/movies.asp.

25. Other legal phenomena "are" Casablanca as well, or at least Casablanca has proved a useful foil for legal analysis in other contexts. See, e.g., Aviam Soifer, Complacency and Constitutional Law, 42 Oнiо ST. L.J. 383 (1981); Daniel J. Steinbock, Refuge and Resistance: Casablanca's Lessons for Refugee Law, 7 Geo. Immigr. L.J. 649 (1993); cf. Richard A. Epstein, Let "The Fundamental Things Apply": Necessary and Contingent Truths in Legal Scholarship, 115 HARV. L. REV. 1288, 1313 (2002) (invoking a line from "As Time Goes By," performed by the piano player Sam (played by Dooley Wilson) in Casablanca); Neil Weinstock Netanel, Copyright Alienability Restrictions and the Enhancement of Author Autonomy: A Normative Evaluation, 24 RUTGERS L.J. 347 (1993):

[A] viewer of the film, Casablanca, would be free to see it as a metaphor for whatever she wishes and to express that viewpoint in critical commentary. She also would be entitled to take inspiration from the film and to borrow from its basic themes, story and characters in creating her own work, so long as her work did not cross the fine line between independent expression and a modified version of the director's and screenwriter's expression.

Id. at 408 .

The enduring popularity of the film has made it an appropriate foil for recent political commentary. See Morgan Meis, Usual Suspect, THE AMERICAN Prospect, (June 20, 2003), at http:// www.prospect.org/webfeatures/2003/06/meis-m-06-20.html (arguing that suicide bombings in Casablanca recall humane themes of Casablanca).

26. See Hunter, supra note 6, at 514-16 (arguing for displacement of cyberspace-as-place 
motion pictures, let alone one particular film. But metaphors and analogies are all but inevitable, not only for understanding computer technology, but for understanding and explaining any area of law. We need them both because we need to develop procedures and tools to guide interpretation and the creation of meaning in legal contexts generally ${ }^{27}$ and because they play a central role in the particular descriptive enterprise of developing, applying and extending precedent. ${ }^{28}$

Law might approach cyberspace as a sui generis phenomenon and deliberately avoid applying policy or precedent from other fields, reasoning instead from principles based on some "true" understanding of the internet itself. Thus, some courts and scholars have tried to address legal issues "in" cyberspace or "on" the internet by focusing on technical characteristics of the network or digital technology rather than on human experiences situated in it. ${ }^{29}$ This perspective includes arguments that cyberspace analysis should focus on the relevant technical "layer" of the internet involved in a particular policy or litigation problem. ${ }^{30} \mathrm{~A}$ different solution suggests deconstructing cyberspace into categories defined by theoretical abstractions. Cyberspace describes a problem of information theory, ${ }^{31}$ property rights theory, ${ }^{32}$ economics ${ }^{33}$ governance and institutional legitimacy, ${ }^{34}$ innovation and creativity ${ }^{35}$ and privacy and security, ${ }^{36}$ among other things.

metaphor); Jonathan H. Blavin \& I. Glenn Cohen, Note, Gore, Gibson, and Goldsmith: The Evolution of Internet Metaphors in Law and Commentary, 16 HARV. J.L. \& TECH. 265, 285 (2002) (arguing for abandonment of search for overarching metaphor for the internet and acceptance of localized metaphors); Timothy Wu, Application-Centered Internet Analysis, 85 VA. L. REV. 1163, 1163-66 (1999) (arguing against application of single analogy for all internet analysis).

27. See George H. Taylor, Critical Hermeneutics: The Intertwining of Explanation and Understanding as Exemplified in Legal Analysis, 76 CHI.-KeNT L. REV. 1101, 1117 (2000) ("The relationship between understanding and explanation itself forms a hermeneutic circle: understanding is mediated by explanatory procedures, and explanation needs contextualization within interpretive understanding.").

28. See generally Dan Hunter, Reason is Too Large: Analogy and Precedent in Law, 50 EMORY L.J. 1197, 1204-29 (2001) (describing cognitive bases for analogical models of legal reasoning).

29. See Frischmann, supra note 2; Marobie-FL, Inc. v. Nat'l Ass'n of Fire Equip. Distribs., 983 F. Supp. 1167, 1176 (N.D. Ill. 1997) (holding World Wide Web user liable for infringement of plaintiff's right to distribute copyrighted work when defendant copied file containing plaintiff's work to web server). The trend under contemporary copyright law to treat all electronic "copying" as infringing "reproduction" under the Copyright Act can be traced to MAI Sys. Corp. v. Peak Computer, Inc., 991 F.2d 511 (9th Cir. 1993).

30. See Wu, supra note 26, at 1194-1203 (using example of debates over scope to be accorded to private ordering "on the internet" to argue that internet analysis should focus on the characteristics of the software application in question); Yochai Benkler, Net Regulation: Taking Stock and Looking Forward, 71 U. COLO. L. REV. 1203, 1260 (2000) (urging recognition of the different layers of the internetphysical, logical and content - and how they relate to one another).

31. See Yochai Benkler, Free as the Air to Common Use: First Amendment Constraints on Enclosure of the Public Domain, 74 N.Y.U. L. Rev. 354, 377-86 (1999).

32. See Trotter Hardy, Property (and Copyright) in Cyberspace, 1996 U. CHI. LEGAL F. 217, 236-58.

33. See Tom W. Bell, Fair Use vs. Fared Use: The Impact of Automated Rights Management on Copyright's Fair Use Doctrine, 76 N.C. L. REV. 557, 579-600 (1998).

34. See A. Michael Froomkin, Habermas@Discourse.net: Toward a Critical Theory of Cyberspace, 116 HARV. L. REV. 749, 855-71 (2003).

35. See LeSSig, THE FutURE OF IDEAS, supra note 10, at 103-41. 
None of these approaches is wrong even though each may teach different things. Cyberspace and the internet represent all of these things: metaphor, technology and theory, even when the lessons of each approach appear to contradict one another. What the technology describes, the theory explains; what the theory explains, the metaphor understands. ${ }^{37}$ What is missing is a meta-analysis, a way to connect the technical, the theoretical and the metaphorical in a way that captures the dynamism of the field. What we have today is a collection of metaphors, each with adherents and impact on the development of the law, applied with no sense that they might be related to one another. ${ }^{38}$ The metaphor may not be the only thing driving legal analysis, but the legal landscape is littered with conflicts produced in part by disagreements over perspective and characterization. ${ }^{39}$

Theoretical, technical and metaphorical approaches tend to assume the existence of an object- "cyberspace," or "the internet," whether those are one thing or twothat is both fixed and distinct. If that characterization continues to make sense remains to be seen. We think and act as if there is "an internet" and "cyberspace," but the border between how people use the internet (or experience cyberspace), and the internet or cyberspace itself, from a technical standpoint, is increasingly blurry. ${ }^{40}$ And neither cyberspace nor the internet is static. If any one thing has characterized both over the last three decades, it is a state of constant, rapid change. Metaphors that rely on mapping characteristics from source phenomenon to target and theories that project their constructs onto objects of analysis have a difficult time analyzing a fast-moving target, large portions of which are being absorbed into the fabric of broader experience. ${ }^{41}$

Finding the "right" metaphor for cyberspace at a universal level may be an

36. See Marc Rotenberg, Fair Information Practices and the Architecture of Privacy (What Larry Doesn't Get), 2001 STAN. TECH. L. REV. 1, $\uparrow \uparrow 51-100$, at http://stlr.stanford.edu/STLR/Symposia/ Cyberspace/00 rotenberg 1/article.htm.

37. See Taylor, supra note 27.

38. In a relatively short time, the Supreme Court's perspective on the internet has undergone a radical transformation. Compare Reno v. ACLU, 521 U.S. 844, 851 (1997) (analyzing federal law regulating access to online pornography from the premise that the internet is a unique and wholly new medium), with Ashcroft v. ACLU, 535 U.S. 564, 583 (2002) (confirming applicability of existing "community standards" obscenity jurisprudence to analysis of follow-on federal law regulating access to pornography). The "speaker centered" analysis of the internet obscenity cases contrasts with the "user centered" analysis applied in the Court's first internet copyright case, New York Times Co. v. Tasini, 533 U.S. 483, 499 (2001) (finding that newspaper publishers infringed copyrights of freelance authors when publishers caused articles to be re-distributed in online computer databases).

39. See Kerr, supra note 2; Hunter, supra note 6, at 472-99.

40. See Agre, Cyberspace as American Culture, supra note 4, at 183-85 (describing the conflation of computing technology and ordinary patterns of human activity); Radin, supra note 5, at 1143-44 (describing the conflation of text and technology). The evolution of both technology and practice from "wired" network communications to "wireless" communications, for data as well as voice, is further breaking down barriers between "online" and "offline" activity. For a perceptive critique of how wireless networks are changing fundamental assumptions about telecommunications regulation, see Yochai Benkler, Some Economics of Wireless Communications, 16 HARV. J.L. \& TECH. 25, 40-47 (2002).

41. See David Nimmer, Brains and Other Paraphernalia of the Digital Age, 10 HARV. J. L. \& TECH. 1, 4-9 (1998) (discussing causes and effects of "despatialization" in cyberspace). 
impossible task. Gibson's characterization of "cyberspace" as a "consensual hallucination" 42 suggested long before cyberspace became "real" in popular understanding that the technology that sustains this form of electronic interaction could be understood only with more than ordinary application of the metaphorical and imaginative arts. I argue, modestly, that cyberspace-as-story, and cyberspaceas-Casablanca as one story in particular, supplies a better and appropriate framework.

I focus on narrative in two distinct, but related, senses. First, there is the modern academic sense of "narrative" as a social construct that integrates diverse phenomena into some meaningful, if necessarily incomplete, whole. ${ }^{43}$ This is partly Robert Cover's nomos:

No set of legal institutions or prescriptions exists apart from the narratives that locate it and give it meaning. For every constitution there is an epic, for each decalogue a scripture. Once understood in the context of the narratives that give it meaning, law becomes not merely a system of rules to be observed, but a world in which we live. ${ }^{44}$

It is also partly what Martha Nussbaum has described and commended as an act of "literary imagination." 45 The narrative permits us to both see the world as it is, by structuring apparently disparate phenomena, and perhaps to understand or imagine, as a writer might do, the world as it might be. ${ }^{46}$ Situating legal problems of cyberspace in the context of a narrative helps us to describe the character of the issues that we face and to derive prescriptions from the narrative structure for resolving those issues.

Second, there is the related but both older and more popular sense of "narrative" as story, as a tale that has power and relevance because it has a beginning, a middle

42. See GIBSON, supra note 19 .

43. The relationships among law, literature and narrative form a rich field of scholarly inquiry. Scholars urging critical examination of jurisprudence from literary, aesthetic and/or narrative perspectives include: MARTha C. Nussbaum, Poetic Justice: The Literary IMAginAtion AND Public Life (1995); Richard Weisberg, Poethics AND Other Strategies of LAW AND Literature (1992); Robin West, NARrative, Authority, AND LAW (1993); Robert M. Cover, Foreword: Nomos and Narrative, 97 HARV. L. REV. 4 (1983). The role of literary perspectives in constructing a normative vision of law and legal practice is explored in the work of James Boyd White. See, e.g., James Boyd White, Acts of Hope: Creating Authority in Literature, Law, AND POLITICS (1994); JAMES BOYd White, JUSTICE AS TRANSLATION: AN ESSAY IN CULTURAL AND Legal Criticism (1990); The Legal Imagination: Studies in the NAture of Legal Thought AND EXPRESSION (1973); JAMES BOYD WHITE, Reading Law and Reading Literature: Law as Language, in HERACLES' BOW: ESSAYS ON THE RHETORIC AND POETICS OF THE LAW (1985).

44. See Cover, supra note 43, at 4-5.

45. See NuSSBAUM, supra note 43 , at 3-12.

46. This is the classic Aristotelian perspective on narrative.

[I]t is not the poet's function to relate actual events, but the kinds of things that might occur and are possible in terms of probability or necessity. The difference between the historian and the poet is not that between using verse or prose; Herodotus' work could be versified and would be just as much a kind of history in verse as in prose. No, the difference is this: that the one relates actual events, the other the kinds of things that might occur. Aristotle, POETICS 51b, at 59 (Stephen Halliwell trans., 1995). 
and an end. The cyberspatial metaphor is this Aristotelian narrative ${ }^{47}$ rather than Platonic essence ("what is the internet?"). Theoretical constructs, metaphors and technologies become characters, settings, themes and plots. In both senses, thinking about cyberspace as a narrative can help lawyers, judges, policy makers and jurors structure intersecting and overlapping arguments and interests about conflicts involving phenomena in cyberspace. ${ }^{48}$ Cyberspace is not a thing, in other words, nor is it a place or merely a collection of wires and bits, nor an instantiation of information theory. Cyberspace is a narrative. Cyberspace is a story. ${ }^{49}$

\section{DISSOLVE TO: CODE-AS-NARRATIVE}

Though this suggestion is obviously-but only partly-metaphorical itself, before proceeding further I should note and respond to the immediate objection that, in many respects, cyberspace is the very antithesis of a narrative, either in the sense that narrative consists of a constructed ordering of apparently disparate phenomena or in the sense that narrative serves as a conventional text. By design, cyberspace has no beginning, middle or end. By design, it has structure only at its most basic technical layers. ${ }^{50}$ Literary theorists who discovered "hypertext" online

47. ARISTOTLE, supra note $46,50 \mathrm{~b}$, at 55 ("[A] whole is that which has a beginning, a middle, and an end."). Cf. Paul Ricoeur, 1 Time and Narrative 31-51 (Kathleen McLaughlin \& David Pellauer trans., 1984) (providing an account of the centrality of narrative in Aristotelian thought to rhetoric and ethics, as well as poetics).

48. See generally Nancy Pennington \& Reid Hastie, A Cognitive Theory of Juror Decision Making: The Story Model, 13 CARDOZO L. REV. 519 (1991) (finding that jurors tend to structure evidence into stories in order to understand confusing and disconnected material).

49. Among social scientists, American Studies scholars and some legal scholars, cyberspace and computer technology have previously been characterized as generators of discourses and products (or features) of narratives. See, e.g., Philip E. Agre, The Next Internet Hero, Technology Review, Nov./Dec. 1997, at 61 ("Every new technology is accompanied by a grand narrative."); Keith Aoki, (Intellectual) Property and Sovereignty: Notes Toward a Cultural Geography of Authorship, 48 STAN. L. REv. 1293 (1996); Christopher BRADFord CHESher, COMPUTERS AS INVOCATIONAL MEdiA (2000) (unpublished Ph.D. dissertation, Macquarie University) (on file with author); RICHARD COYNE,

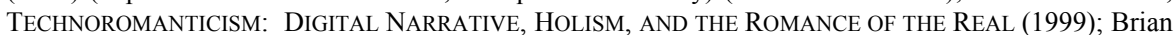
F. Fitzgerald, Software as Discourse: The Power of Intellectual Property in Digital Architecture, 18 CARdozo ARTS \& ENT. L.J. 337 (2000); N. Katherine Hayles, How We BeCAME Posthuman: Virtual Bodies in Cybernetics, Literature, AND Informatics (1999); Rob Kling, Hopes and Horrors: Technological Utopianism and Anti-utopianism in Narratives of Computerization, in COMPuterization and Controversy: Value Conflicts and Social Choices, at 40 (Rob Kling ed., 2d ed. 1996); Brenda Laurel, Computers as Theatre (1991); David E. Nye, Narratives AND Spaces: TeChNology and the Construction of AMERican Culture (1997); ANDREW Ross, Strange Weather: Culture, Science and Technology in the Age of Limits (1991); Vivian Sobchack, New Age Mutant Ninja Hackers: Reading Mondo 2000, 92 S. ATLANTIC Q. 569 (1993).

50. This statement echoes the "end-to-end" (or "e2e") design principle on which the technology of the internet is based.

The e2e argument organizes the placement of functions within a network. It counsels that the 'intelligence' in a network should be located at the top of a layered system — at its 'ends,' where users put information and applications onto the network. The communications protocols themselves (the 'pipes' through which information flows) should be as simple and as general as possible.

Mark A. Lemley \& Lawrence Lessig, The End of End-to-End: Preserving the Architecture of the internet in the Broadband Era, 48 UCLA L. REV. 925, 930-31 (2001). 
in the mid-1990s foresaw the end (or at least the compromising) of the traditional novel along with the end to the traditional physical bounded-ness of the book. ${ }^{51} \mathrm{~A}$ novel's conventional narrative structure requires the linearity defined by the book. Online hypertext encourages, or at least permits, the reader to create a non-linear experience. Narrative theory, then, should have little application to hypertext or to cyberspace.

This argument eventually made its way to law, both in the larger law of "cyberspace" and in the better-defined field of copyright law. Initial efforts to define a law of "cyberspace" focused on its boundless nature and on the fact that conventional state-based legal regulation could not be sustained. ${ }^{52}$ The lack of "bounded-ness" in cyberspace implies a corresponding shift in the kinds of stories that can be told about law. ${ }^{53}$ Copyright commentators have noted that the internet lacks the material characteristics that defined traditional copyright law. In particular, the lack of "book-ish"-ness of information created, stored and distributed on electronic networks has been a cause for concern on the ground that it appears to signify the passing of an effective doctrine of first sale,${ }^{54}$ among other things. The question "What is a book?" has to be re-asked when text is presented in electronic form. So far, it appears, an electronic book is not "a book." ${ }^{\text {"5 }}$ Copyright's conventional stories do not apply.

But the lack of boundaries in cyberspace may be more apparent than real. More recent literary criticism has grasped this. Cyberspace is not necessarily defined by

51. See, e.g., J. David Bolter, Writing Space: The Computer, Hypertext, AND the History OF Writing 107-46 (1991); Richard A. LANHAM, The Electronic WORD: DEMOCRACY, TeChNOlogy, AND the ARTS 124-25 (1993); George P. LANDOW, HyPerteXt 2.0: THE CONVERGENCE OF CONTEMPORARY CRITICAL THEORY AND TECHNOLOGY 49-60, 178-92 (1997); JANET H. Murray, Hamlet on the Holodeck: The Future of NARRative IN Cyberspace 65-94, 173-75 (1997); Robert Coover, The End of Books, N.Y. TIMES, June 21, 1992, (Book Review), at 1. Early essays investigating the implications of computer technology for the concept of "the book" are collected in THE FUtURE OF THE BOOK (Geoffrey Nunberg ed., 1996). The idea of "hypertext" is generally traced to Vannevar Bush, As We May Think, 176 The AtlantiC MonTHLY No. 1, at 101-08 (July 1945).

52. This position is most clearly associated with David R. Johnson \& David Post, Law And Borders-The Rise of Law in Cyberspace, 48 Stan. L. Rev. 1367 (1996). Johnson and Post's article inspired a response (see Jack L. Goldsmith, Against Cyberanarchy, 65 U. CHI. L. REV. 1199 (1998) (contending that cyberspace presents an unexceptional range of jurisdictional and choice-of-law problems)) and a reply (see David G. Post, Against "Against Cyberanarchy," 17 BERKELEY TECH. L.J. 1365 (2002) (maintaining unrepentant exceptionalism)).

53. See Shulamit Almog, From Sterne and Borges to Lost Storytellers: Cyberspace, Narrative, and Law, 13 Fordham Intell. Prop. Media \& ENT. L.J. 1 (2002). With its essentially dynamic character:

The internet initiates and continuously induces important shifts in our storytelling practices and narrative cognizance. These shifts carry significant implications in the domain of law. They influence the way we practice law and the way we perceive it. They affect our comprehension of law and the range of anticipations, hopes, and emotions related to it.

$I d$. at 3 .

54. See Bartow, supra note 17 , at 110-18.

55. See Random House LLC v. Rosetta Books LLC, 150 F. Supp. 2d 613 (S.D.N.Y. 2001) (denying a motion for preliminary injunction brought by a book publisher authorized to publish novel "in book form" against electronic "book" publisher distributing same novel in electronic form), aff' $d$, 283 F.3d 490 (2d Cir. 2002). 
its form and format, as a traditional book is, but by the production of the form itself. Cyberspace does not have an essence and instead is determined and bounded by the processes by which it is created and experienced. The boundaries of cyberspace are recursive, generated dynamically and constantly re-determined, rather than static. Boundaries do exist, if in a non-traditional sense. ${ }^{56}$ At its most basic technical layer, cyberspace is defined by software, embodied in the programs and protocols that enable different computers to transmit data between them. Protocols are sets of rules that define the conditions under which computer programs will operate; that is, they set limits on the behavior of computer systems. Computer programs do likewise, in that they set limits on the behavior of both computers and their human users. Those limits define the scope of permitted conduct. Code regulates. ${ }^{57}$ Even hypertext is not truly boundless. The manner in which a reader of hypertext can jump from link to link is determined by HTML ${ }^{58}$ codes that specify the existence of, and connections between, links. The reader is merely establishing one pattern from among a large number of patterns whose potential is embedded in the software. There are many beginnings and many ends, rather than one of each. All of these choices exist within the boundaries set by the technology. The reader or user chooses and, in doing so, selects the boundaries of his or her own experience.

A comparable notion is present in legal scholarship, though described in different terms. From initial arguments that legal doctrine would be forced to accommodate the essential openness and indeterminacy of the internet, ${ }^{59}$ the legal literature now focuses more precisely on the ways in which cyberspace both creates and can help resolve boundary problems. ${ }^{60}$ Code regulates not only in a purely

56. Joseph TABBi, Cognitive Fictions xi (2002) (“A similar interdependence [between the individual and the environment], through which a bounded and stable structure is continually produced, might better describe what is actually going on within today's changing media environment."). This perspective identifies traditional text-based narratives as a historically contingent instantiation of a cognitive framework for the recognition of meaning in context. The narrative construct does not depend on a particular technology. See id. The same argument is evident in a recent short story by Richard Powers. See Richard Powers, Literary Devices, 6 ZOETROPE, No. 4 (Winter 2002), which echoes the hermeneutic perspective offered above. Also See Taylor, supra note 27, at 1123:

The model for law need not necessarily derive from the deterministic, nomological form of explanation commonly identified in the physical sciences but may find more appropriate analogue in the interrelation of regularity and exception found in biology. A sophisticated narrative approach - informed by both interpretive understanding and explanation-can be an appropriate, indeed arguably is the most appropriate, methodology in law.

57. Lawrence Lessig makes an extended argument in support of this point in LAWRENCE LESSIG, CODE AND OTHER LAWS OF CYBERSPACE (1999). See also MitCHELl, supra note 5, at 111.

58. HTML stands for Hyper Text Markup Language, the software protocol used to frame the basic appearance of pages on the World Wide Web.

59. See Johnson \& Post, supra note 52

60. See, e.g., Paul Schiff Berman, The Globalization of Jurisdiction, 151 U. PA. L. REV. 311, 321 22 (2002) (attempting to rethink jurisdictional questions in terms of dynamic community affiliations enabled by the internet). The idea that technology can create borders, and thus, meaning, is not new, at least in internet time. See generally Joel R. Reidenberg, Lex Informatica: The Formulation of Information Policy Rules Through Technology, 76 TEX. L. REV. 553 (1998); Joel R. Reidenberg, Governing Networks and Rule-Making in Cyberspace, 45 EMORY L.J. 911 (1996). And the unconventional idea of property (an artifact typically characterized as timeless) as narrative has been 
behavioral sense, but also in a meaningful legal sense, by dynamically shaping the choices faced by both communities and individuals online. What I suggest, then, is that this emerging dynamic notion of boundaries and limits in cyberspace, from both literary and legal perspectives, can be borrowed to construct the foundations for a narrative, a story, of cyberspace.

\section{CUT TO: LEARNING FROM CASABLANCA}

Narrative theory might stop at this point and encourage scholars and other critics to examine cyberspace, its texts and other forms, for explicit and implicit narratives. There is not a single story of cyberspace, but multiple dynamicallystructured stories of cyberspace. ${ }^{61}$ The best of them, the most useful stories for conceptualizing this phenomenon, emerge organically from critical understandings of the experience of cyberspace.

Yet, while narrative at such an abstract level might be valuable critically, it is of relatively little use practically to the sitting judge or the practicing lawyer. The judge and the lawyer may value story-telling more for its role in advocacy than for its help in conceptualization. They care less for the philosophical or psychological justifications for narrative and more for its effectiveness. A good story turns the abstract and the confusing into the relatively structured and concrete. ${ }^{62}$ Pragmatically (and frankly, somewhat speculatively) speaking, I suggest not just that cyberspace is $a$ story, but that it is some particular story.

To press my argument to this level, I ask: if cyberspace is a story, then what story could it be? It is clearly a great one. It is timeless, yet of its time, ${ }^{63}$ both popular and elite, with international and domestic dimensions, compelling characters, ${ }^{64}$ multiple plots, ${ }^{65}$ cynicism and romance,${ }^{66}$ comedy and drama ${ }^{67}$ and

explored in the context of property theory generally. See Carol M. Rose, Property as Storytelling: Perspectives from Game Theory, Narrative Theory, Feminist Theory, 2 YALE J.L. \& Human. 37, 38-39 (1990); Anupam Chander, The New, New Property, 81 TEX. L. REV. 715 (2003).

61. It might be argued that existing metaphorical efforts in cyberspace analysis (see supra notes 519 and accompanying text) constitute narratives of their own.

62. See Philip N. Meyer, Making the Narrative Move: Observations Based Upon Reading Gerry Spence's Closing Argument in the Estate of Karen Silkwood v. Kerr-McGee, Inc., 9 ClinICAL L. ReV. 229, 244-46 (2002). On the use of literary devices in judicial opinions, see Patricia M. Wald, The Rhetoric of Results and the Results of Rhetoric: Judicial Writings, 62 U. CHI. L. REV. 1371, 1386-90 (1995).

63. The myth that the internet was designed to survive a nuclear war has been largely debunked, but it remains the case that much of the research that produced the computer networks that evolved into today's internet was funded through the Department of Defense during the Cold War. See M. MitChell WALDROP, THE DREAM MAChinE: J.C.R. LiCKLIDER AND THE REVOLUTION THAT MADE COMPUTING PERSONAL 259-332 (2001)

64. Any "cast of cyberspace" is inevitably incomplete. Some of the better known names include John Perry Barlow (cyberspace rhetoritician), Vinton Cerf and Bob Metcalfe (networking pioneers), the late Jon Postel (original keeper of the domain names registry), Marc Andreesen and Jim Clark (popularizers of the Netscape Navigator web browser) and Steve Case (founder of America Online). See Agre, The Next Instant Hero, supra note 49, at 61 (anticipating the emergence of the "public hacker" as the next hero of the grand narrative of the internet).

65. See infra notes $128-36$ and accompanying text. 
original $^{68}$ and derivative ${ }^{69}$ elements alike. A classic novel might do here, but in contemporary culture, motion pictures provide the legal system's preferred currency. ${ }^{70}$ No motion picture fits this bill better than Casablanca.

Casablanca was released in late 1942 and was named Best Picture in 1943 by the Academy of Motion Picture Arts and Sciences. ${ }^{71}$ Its rise to iconic status began shortly after the premature death of its star, Humphrey Bogart, in 1957. ${ }^{72}$ Since then, it has remained one of a handful of films universally regarded as "classics."

66. See infra notes $92-94$ and accompanying text.

67. Efforts to cast internet policy debates as arguments over use of the "commons" (see supra notes 6-10) draw on property theories that echo the forms of Greek drama. See Carol Rose, The Comedy of the Commons: Custom, Commerce, and Inherently Public Property, 53 U. CHI. L. REV. 711 (1986); Michael A. Heller, The Tragedy of the Anticommons: Property in the Transition from Marx to Markets, 111 HARV. L. REV. 621 (1998).

68. See Lawrence Lessig, The Law of the Horse: What Cyberlaw Might Teach, 113 HARV. L. REV. 501, 514-34 (1999).

69. See Frank H. Easterbrook, Cyberspace and the Law of the Horse, 1996 U. CHI. LEGAL F. 207, 207-08.

70. See NuSSBAUM, supra note 43, at 6. For examples of legal scholarship framed by film, see Shubha Ghosh, The Merits of Ownership; Or, How I Learned to Stop Worrying and Love Intellectual Property, 15 HARV. J.L. \& TECH. 453 (2002) (Dr. Strangelove); Ann Althouse, Invoking Rashomon, WiS. L REV. 503 (2000) (Rashomon); Steven L. Winter, Bull Durham and the Uses of Theory, 42 STAN. L. REV. 639 (1990) (Bull Durham); Robert B. Porter-Odawi, Two Kinds of Indians, Two Kinds of Indian Nation Sovereignty: A Surreply to Professor LaVelle, 11 KANSAS J. L. \& PUB. POL'y 629 (2002) (The Matrix). Cf. Aviam Soifer, Beyond Mirrors: Lawrence Friedman's Moving Pictures, 22 LAW \& SOC'Y REV. 995 (1988) (analogizing Professor Friedman to a one-man Warner Brothers motion picture studio); Jeffrey L. Harrison \& Amy R. Mashburn, Jean-Luc Godard and Critical Legal Studies (Because We Need the Eggs), 87 MicH. L. REV. 1924 (1989) (comparing Critical Legal Studies to French New Wave cinema). Cf. United States v. Syufy Enterprises, 903 F.2d 659 (9th Cir. 1990) (Kozinski, J.) (opinion analyzing antitrust claims against motion picture theater operator that is rife with references to motion pictures); The Syufy Rosetta Stone, 1992 BYU. L. REV. 457 (decoding Judge Kozinski’s opinion).

71. See 75th Annual Academy Awards, at http://www.oscar.com/legacy/pastwin/picture6.html. The making and subsequent history of Casablanca are documented in ALJEAN HARMETZ, ROUND UP The Usual Suspects: The MaKing of CASABlanca-Bogart, Bergman, AND World War II (1992); JefF SpIEgel, The CASABlanCA COMPANION (1992); William Donnelly, Love and Death in Casablanca, in Persistence of Vision: A Collection of Film CRiticism (Joseph McBride ed., 1968); Charles Francisco, You Must Remember This (1980); Casablanca (Richard J. Anobile ed., 1974).

72. Following Bogart's death, a theater in Harvard Square began screening Casablanca, building a cult following for the film that eventually spread across the country. See Old Bogart Films Packing Them In, N.Y. TIMES, Jan. 28, 1965, at 19; About the Brattle Theatre, at http://www.brattlefilm.org/ timeline.html. The film's place in popular culture was likely secured by 1971 with the release of PLAY IT AGAIN, SAM (Paramount Pictures 1972), starring Woody Allen as a neurotic single male haunted by the need to model the worldly cynicism of Bogart's character in Casablanca.

73. The film itself has been the subject of some legal analysis. Warner Brothers, which produced the motion picture, twice attempted to adapt the same material into a "prequel" television series. In its second attempt, the studio was sued by the authors of the original play. See Burnett v. Warner Bros. Pictures, 493 N.Y.S.2d 326 (App. Div. 1985) (affirming order granting summary judgment to the defendants on the ground that the plaintiffs had assigned to the defendants all rights in the work). Casablanca is the basis of an apocryphal copyright law legend involving the Marx Brothers. Groucho et al. were threatened by a humorless Warner Brothers executive over the rights to the name "Casablanca" while preparing the film, A Night in Casablanca. With characteristic wit, Groucho threatened a countersuit based on the Warners' misuse of "Brothers," and the matter was dropped. See SIVA VAIDHYANATHAN, COPYRIGHTS \& COPYWRONGS: THE RISE OF INTELLECTUAL PROPERTY AND HOW IT 
Casablanca is pure character, plot and theme, a fact that makes it far better for my purpose than any film highly regarded more for cinematic techniques than for pure emotional appeal. More than fifty years have passed since its initial release, but no contemporary popular or critical audience can fail to understand Casablanca. ${ }^{74}$

The plot of Casablanca appears to be a simple one. An expatriate American, Rick Blaine (played by Bogart), is marooned in French Morocco during the early stages of World War II for reasons that are left obscure. ${ }^{75}$ While managing his nightclub ("Rick's Café Americain") and respecting the interests of the local French prefect (played by Claude Rains), Rick encounters an old flame recently arrived in Casablanca, Ilsa Lund (a Swede, played by Ingrid Bergman) ${ }^{76}$ Ilsa is accompanied by her Czech husband, Victor Laszlo (played by Paul Henreid), who happens to be the most famous and notorious Resistance fighter in Europe and who happens to have arrived in Casablanca one short step ahead of his Nazi pursuers. The Nazis (personified by Major Strasser, played by Conrad Veidt) track Laszlo to Rick's, eventually forcing Rick to decide whether his love for Ilsa means reclaiming her for his own or letting her stay with husband Laszlo as Laszlo tries to escape to Lisbon and then to America. By the end of the movie, Rick appears to have decided to join Ilsa on board the Lisbon plane. At the last moment, Laszlo reappears, putting Rick to the film's climactic choice. ${ }^{77}$

Of course, the love story between Rick and Ilsa is not the story of Casablanca at all. The movie opens with the murder of two German couriers carrying "letters of transit" that entitle their bearer to unquestioned passage out of Casablanca. The prefect, Captain Renault, correctly traces both the letters and the murderer to

Threatens Creativity 1-2 (2001) (citing Groucho Marx letter of 1944, published in MarX, The GROUCHO LETTERS: LeTTERS TO AND FROM GROUCHO MARX (1967)). Groucho's famous reply appears to have been more publicity stunt than genuine outrage. The original concept for $A$ Night in Casablanca was a parody of the original Casablanca, and Warner Brothers may have had legitimate grounds to object to more than mere misuse of the title. See A Night in Casablanca (2000), at http://www.snopes.com/movies/films/anightin.htm.

74. See Umberto Eco, Casablanca: Cult Movies and Intertextual Collage, 47 SuBSTANCE No. 2, at 3-12 (1985), reprinted in UMBERTO ECO, TRAVELS IN HYPER REALITY: ESSAYS 197-211 (1986).

75. Rick was in Paris when the German army arrived to occupy that city. He escaped to Casablanca. Why he chose Casablanca is part of the man's mystery:

(Renault) I have often speculated on why you don't return to America. Did you abscond with the church funds? Did you run off with a Senator's wife? I like to think that you killed a man. It's the romantic in me. (Rick) It was a combination of all three. (Renault) Then what in heaven's name brought you to Casablanca? (Rick) My health. I came to Casablanca for the waters. (Renault) Waters? What waters? We're in the desert. (Rick) I was misinformed. HOWARD KoCH, CASABLANCA: SCRIPT AND LEGEND 59 (3rd ed. 1973).

76. Rick, speaking to no one in particular, considers the likelihood that he would ever see Ilsa again: "Of all the gin joints in all the towns in all the world, she walks into mine!" Id. at 94.

77. On the tarmac, Rick tells Ilsa that she has to go with her husband:

(Rick) Inside of us we both know you belong with Victor. You're part of his work, the thing that

keeps him going. If that plane leaves the ground and you're not with him, you'll regret it ....

Maybe not today, maybe not tomorrow, but soon, and for the rest of your life. (Ilsa) But what

about us? (Rick) We'll always have Paris. We didn't have it, we'd lost it until you came to

Casablanca. We got it back last night. (Ilsa) And I said I would never leave you . . . . (Rick) And you never will. 
Rick's, the center of the social and political networks that characterize the city. Quietly, Rick accepts the letters for safekeeping from his friend, broker to the local underworld and the presumed murderer Ugarte (played by Peter Lorre), but Rick refuses to shield Ugarte from arrest by Renault. The letters serve as what Alfred Hitchcock would later call the movie's "macguffin," the plot device around which all other elements of the story revolve but that means relatively little in itself. ${ }^{78}$ Ilsa and Laszlo desperately need the letters in order to escape from Casablanca. The Nazis desperately need the letters in order to prevent their escape. Captain Renault wants the letters in order to keep Laszlo in Casablanca, please the Nazis and keep his position. Rick professes neutrality in the face of their various schemes. The fate of the letters remains unclear until the very end of the film, when the Lisbon plane is about to depart and Rick must choose whether to use the letters for himself and Ilsa or to offer them to Ilsa and Laszlo.

But the melodrama of the letters of transit is no more the real story of Casablanca than is its love story. Rick is an American who fought on the Loyalist (losing) side in the Spanish Civil War. He professes neutrality in the fight against the Nazis,${ }^{79}$ but when the Nazis show up in Casablanca (and in Rick's Café) in pursuit of Laszlo, his cynicism is challenged. Whether to reclaim Ilsa or to let her go and whether to keep the letters of transit or to give them to Ilsa and Laszlo are political questions. The film was produced in 1942, at a point when the German Army controlled much of North Africa and the outcome of the war was hardly assured. Casablanca is political propaganda. Is Rick an American fighting for truth and justice both at home and abroad, or will his cynicism and isolationism allow him to permit the Nazis to arrest Laszlo and crush the idealism that he represents? The corrupt Renault faces a similar choice. Early in the film Renault cooperates with the Nazis in investigating the murder of the German couriers by arresting Ugarte and closing Rick's. ${ }^{80}$ Renault's friendship helps to eventually persuade Rick to conspire in the murder of the Nazi Strasser ${ }^{81}$ that allows Laszlo and Ilsa, ultimately, to board the Lisbon plane together. Rick and Renault close the film by walking off together into the mist of the night, making plans to join the

78. See Ken Mogg et Al., The Alfred HitchCock Story 93 (1999).

79. Ugarte, running from French police inside the nightclub, encounters Rick:

(Ugarte) Rick! Rick, help me! (Rick) Don't be a fool. You can't get away. (Ugarte) Rick hide me. Do something! You must help me, Rick. Do something! Rick! Rick! (Ugarte is wrestled away.) . . . . (Customer) When they come to get me, Rick, I hope you'll be more of a help. (Rick) I stick my neck out for nobody.

KocH, supra note 75 , at 67-68.

80. Renault gives the order to close Rick's in response to a German request:

(Renault) Everybody is to leave here immediately! This café is closed until further notice! Clear the room at once! (Rick) How can you close me up? On what grounds? (Renault) I am shocked, shocked to find that gambling is going on in here! (Croupier) You're [sic] winnings, sir. (Renault) Oh. Thank you, very much. Everybody out at once!

Id. at 145

81. Renault witnesses Rick shoot the German Strasser. French gendarmes runs up to Renault, waiting for instructions: "(Renault) Major Strasser's been shot. (Pause) Round up the usual suspects." Id. at 181 . 


\section{French Resistance. ${ }^{82}$}

Any one of these stories alone would make Casablanca an ordinary film. Indeed, the thing to know about Casablanca is that the film, piece by piece, is almost entirely unoriginal. Even the film's description of its Moroccan setting is little more than a collage of Hollywood stereotypes. ${ }^{83}$ Yet the multiplicity of plots, the banality of the setting and the almost chaotic manner in which the film was written and shot clearly create something that is greater than the sum of its parts. ${ }^{84}$ In the words of the critic Umberto Eco:

Forced to improvise a plot, the authors whipped up a little of everything, and everything they put in came from a repertoire that had stood the test of time. When only a few stock formulas are used, the result is simply kitsch. But when the repertoire of formulas is used wholesale, the result is an architecture like Gaudi's Holy Family Church [Sagrada Familia] - the same vertigo, the same stroke of brilliance. $^{85}$

In this sense - an entirely unoriginal collection of experiences that has a comprehensively transformative effect-Casablanca is the perfect story for (and of) cyberspace. Casablanca is a classic because it is still the same old story, ${ }^{86}$ told in a starkly original way. ${ }^{87}$ It acknowledges the critics who argue that there is nothing new here, just the same old themes. ${ }^{88}$ It accommodates the critics who argue that there is a connectedness to these older phenomena online that combines old themes in new ways. ${ }^{89}$ And its endurance over the last 60 years suggests that its power derives not merely from its origins but at least equally from the meaning projected onto it by generations of fans. Casablanca, as Eco implies, derives its

82. The fog of the night envelops the airport runway: "(Rick, walking off with Renault) Louis, I think this is the beginning of a beautiful friendship." Id . at 31 .

83. According to the script, "[T]he facades of the Moorish buildings [give way] to a narrow, twisting street crowded with the polyglot life of a native quarter. The intense desert sun holds the scene in a torpid tranquility. Activity is unhurried." See KocH, supra note 75 , at 37, 182. I have to resist the temptation to metaphorically characterize cyberspace as Casablanca, the fictional place. Cyberspace-asa-fictional-film-environment has been explored in STUART BIEGEL, BEYOND OUR CONTROL? CONFronting the Limits of OuR Legal System in the AgE OF CyBerspace 12-18 (2001) (comparing cyberspace to the "idea of the West" as exemplified in Shane and other Western films), and High NoOn On the Electronic Frontier: ConCEPTUAL IsSUeS In Cyberspace (Peter Ludlow ed., 1996).

84. See HARMETZ, supra note 71, at 227-38 (describing the writing and shooting of the climactic airport scene). Eco describes the result as the film's "glorious incoherence." Eco, supra note 74, at 4.

85. Eco, supra note 74 , at 6 .

86. The musical theme of Casablanca is the popular tune, "As Time Goes By." The lyrics include the lines: "It's still the same old story, a fight for love and glory, a case of do or die." See Herman Hupfeld, As Time Goes By (1931), available at http://www.cyberblanca.com/lyrics.html.

87. Renault's reference to rounding up "the usual suspects" both opens the film (in his conversation with Major Strasser, who wants to know what Renault is doing to investigate the murder of the couriers) and closes it (in his instructions to the gendarmes, who are meant to investigate the murder of Strasser himself). In each case, both the characters and the audience understand that the phrase alludes to nothing more than an empty gesture of authority.

88. See Easterbrook, supra note 69.

89. See Lessig, supra note 7. 
brilliance from its reception and interpretation as much as from its production. ${ }^{90}$

\section{DISSOLVE TO: THE NARRATIVES OF CYBERSPACE LAW}

How then to map cyberspace to Casablanca, or Casablanca to cyberspace? It might or might not do as a matter of film criticism to see Casablanca as an eerie, early example of cyberspatial boundlessness. ${ }^{91}$ The numerous of doctrinal and policy problems involving the internet overlap with one another to a degree that it can be difficult to keep their plot lines and major interests distinct, even assuming that distinctions of this sort are feasible and desirable. But both interests and their development can be roughly organized along the same three plot lines that characterize the film. This is not mere entertainment. There is a method, which is both descriptive (showing how different interests in fact play multiple parts) and predictive (offering one, hopeful version of ongoing developments).

\section{A. A Cyberspace Love Story}

Rick loves Ilsa. Ilsa loves Rick. In a flashback sequence in Casablanca, we learn that they had a love affair in pre-war Paris that was cut short unexpectedly as the Germans arrived, leaving Rick bitter and alone. Ilsa later appears with her husband, Victor Laszlo, in Rick's Café, suggesting the rekindling of the romance ${ }^{92}$ that cannot flourish so long as Laszlo is with her and needs her. When the opportunity arises for one pair of lovers to leave Casablanca on the Lisbon plane, who will go? The romantic pair-Rick and Ilsa? Or the pragmatic pair-Laszlo and Ilsa?

The story of cyberspace has been an equivalent tale of romance and pragmatism. When the internet first burst upon popular consciousness in the early 1990s, pop philosophers of the network proclaimed that it was definitively different and

90. As the film writer Aljean Harmetz writes:

There are better movies than Casablanca, but no other movie better demonstrates America's mythological vision of itself - tough on the outside and moral within, capable of sacrifice and romance without sacrificing the individualism that conquered a continent, sticking its neck out for everybody when circumstances demand heroism. No other movie has so reflected the moment when it was made - the early days of World War II- and the psychological needs of audiences decades later.

HARMETZ, supra note 71 , at 6 .

91. Eco evokes this timeless, placeless sense of the film:

Casablanca has succeeded in becoming a cult movie because it is not one movie. It is "the movies." And this is the reason it works, in spite of any aesthetic theory. For it stages the powers of Narrativity in its natural state, before art intervenes to tame it.

Eco, supra note 74, at 10.

92. Rick despairs at Ilsa's appearance, see supra note 77, but he cannot resist the pull of their relationship:

(Rick, to Sam, the piano player) You know what I want to hear. (Sam) No, I don't. (Rick) You

played it for her and you can play it for me. (Sam) Well, I don't think I can remember it. (Rick)

If she can stand it, I can. Play it! (Sam) Yes, boss. (Sam starts to play “As Time Goes By."). KocH, supra note 75 , at $94-95$. 
special, uncolored by crass commercial interests and destined to remain ever so. ${ }^{93}$ This internet was to be free of corporate interests and commercial demands. It would be a platform for pure play, self-expression, innovation and creativity. To the extent that "real world" interests began to intrude, those interests were to be dealt with at a distance. The internet was special and different and demanded distinct treatment. ${ }^{94}$ Even today, the romantic vision of the internet persists, among other places, in appeals for preserving the "end to end" network architecture of the internet as supporting a "commons" for creativity and innovation and for ending the "digital divide" between internet-haves and internet-have nots, among other places. The internet is special.

The internet is not, of course, all Rick and Ilsa. It is also Ilsa and Laszlo, representing the familiar, the pragmatic, even the commercial and the corporate. The internet could not remain insulated from the demands of the outside world for long. As the German army intruded on Rick's romance with Ilsa, the business community intruded on the independent internet, ${ }^{95}$ building business models and demanding the regulation of domain name space, copyright and trademark use. Business was not the only demanding third party. Use of the internet by individuals and consumers created expectations regarding form and content that were not easily satisfied by a "pure" internet vision. The astonishing early growth of America Online was an accommodation of consumer as well as business interests, an enormous private enclave of "content" and regulation directly at odds with the original philosophy of the open internet. ${ }^{96}$ Consumer interests also brought demands for consumer protection, ${ }^{97}$ for relief from unwanted email ("spam") and even for democracy and accountability in internet governance. ${ }^{98}$

93. See John Perry Barlow, A Declaration of the Independence of Cyberspace (February 8, 1996), at http://www.eff.org/ barlow/Declaration-Final.html.

94. See Johnson \& Post, supra note 52, at 1370-76.

95. The internet was opened to commercial traffic in 1995 when the National Science Foundation stopped supplying backbone services. As a result, the NSF's Acceptable Use Policy, which forbade commercial traffic on its facilities, ceased to play a significant role in influencing internet activity. See Michael Kende, The Digital Handshake: Connecting Internet Backbones, 11 CommLAW ConspeCtus 45, 47-48 (2003); Jay P. Kesan \& Rajiv C. Shah, Fool Us Once Shame on You-Fool Us Twice Shame on Us: What We Can Learn from the Privatization of the Internet Backbone Network and the Domain Name System, 79 WASH. U. L.Q. 89, 111-130 (2001).

96. See Mark A. Lemley, The Law and Economics of Internet Norms, 73 CHI.-KENT L. REV. 1257, 1281 (1998) (noting eventual failure of the On-Line Service Provider (OSP) "enclave" model as more and more subscribers turned to AOL for its Internet Service Provider (ISP) facilities).

97. See, e.g., Mark Cooper, Antitrust as Consumer Protection in the New Economy, 52 HASTINGS L.J. 813 (2001) (on behalf of the Consumer Federation of America, analyzing antitrust claims in United States v. Microsoft Corp., 87 F. Supp. 2d 30, 44 (D.D.C. 2000), as forms of consumer protection). Application of trademark law principles to internet commerce also could be considered a form of consumer protection, though actual application of trademark law online has tended to focus more on the interests of trademark holders than on the interests of consumers. See Mark A. Lemley, The Modern Lanham Act and the Death of Common Sense, 108 YALE L.J. 1687, 1701-03 (1999).

98. See, e.g., A. Michael Froomkin, Wrong Turn in Cyberspace: Using ICANN to Route Around the APA and the Constitution, 50 DuKE L.J. 17, 105-65 (2000) (arguing that the U.S. Department of Commerce supported the creation of the Internet Corporation for Assigned Names and Numbers (ICANN) in order to address concerns over American control of the internet, but in doing so avoided having to confront legitimate questions about democracy and government control). 
With the forces of romantic openness confronting the forces of both business and consumer-driven pragmatism, how does this tale end? We cannot know yet, though we can discern some of the relevant players. Government, at international, national, and local levels, has an important (if sometimes self-interested) role to play, just as Renault's corrupt involvement in Rick's affairs was essential to resolution of the love affair in Laszlo's favor. The government plays both sides of this game, however: Ilsa leaves with Laszlo, but Renault himself walks off to join the French Resistance in the end with Rick. Perhaps one should not write off government regulation of the internet altogether. There are also the intermediary interests, those who have no stake in the ultimate resolution of the story but who wish only to profit from transactions along the way. Ugarte, who traffics in the letters of transit, and Ferrari (played by Sidney Greenstreet), a competitor of Rick who buys Rick's Café, represent intermediary institutions of all sorts, both commercial (internet service providers and online service providers) and noncommercial (the Internet Corporation for Assigned Names and Numbers, the World Intellectual Property Organization). Strasser, the German major, stands in, not for a player or plot device, but for a theme. He and the Germans are the antithesis of romance. ${ }^{99}$ Strasser has no interest in the assignment of Ilsa's affections. He wants to both imprison Laszlo and close Rick's Café, to exercise complete and perfect control over Casablanca. The romantic vision of the internet holds it as a perfectly open space. Strasser's vision of the internet is one of perfect "end to end"100 control.

\section{B. A Cyberspace Melodrama}

Will the Nazis capture Laszlo? Will Captain Renault help the Nazis, or will he remain loyal to his friend Rick? Will Rick help the Nazis, or will he remain loyal to his former love Ilsa? What will happen to the letters of transit? Will the Bulgarians get out of Casablanca? ${ }^{101}$ Melodrama is the popular dramatic form of

99. The literary irony in this stereotype is inescapable. The Romantic Movement, celebrating the creative imagination of the individual, originated in German (and French) literature.

100. Cf. Lemley \& Lessig, supra note 50.

101. One of the melodramatic subplots of Casablanca involves a young refugee couple from Bulgaria, trying to escape to America. The wife is prepared to sacrifice her honor to Renault in exchange for permission to leave Casablanca. She comes to Rick to find out whether Renault can be trusted:

(Annina) We come from Bulgaria. Oh, things are very bad there, M'sieur. A devil has the people by the throat. So, Jan and I, we, we do not want our children to grow up in such a country. (Rick) So you decided to go to America. (Annina) Yes, but we have not much money, and traveling is so expensive and difficult. It was much more than we thought to get here. And then Captain Renault sees us and he is so kind. He wants to help us. (Rick) Yes, I'll bet. (Annina) He tells me he can give us an exit visa, but we have no money. (Rick) Does he know that? (Annina) Oh, yes. (Rick) And he is still willing to give you a visa? (Annina) Yes, M'sieur. (Rick) And you want to know ... . (Annina) Will he keep his word? (Rick) He always has.

KOCH, supra note 75, at 134-35. Rick frustrates Renault's plan by fixing a round of roulette, enabling the Bulgarians to purchase their exit visas for cash and confirming Renault's suspicions about the nobility beneath Rick's cynical veneer. 
good and evil, winners and losers, heroes and villains. The initial conflict, the climax and the resolution count as much as, if not more than, any apparent lesson taught by the story. The audience pays to participate vicariously in the chase, the hunt, the betrayal and redemption.

These are the questions posed by business and commerce on the internet, and they are also the questions of the distribution of entitlements online generally. The demise of transaction costs in the electronic age is now a truism. ${ }^{102}$ As transaction costs decrease, it matters less where initial entitlements are allocated and more that market participants can negotiate over their eventual distribution. We watch the evolution of the law of electronic contracting and online "access" as a multigenerational negotiation over the quantum of disclosure required of a firm before a contracting partner is bound by offered terms and conditions. ${ }^{103}$ The answer may not matter if firms and individuals can easily and effectively avoid being bound in any event. Expansive (or limited) intellectual property rights on the internet are of interest in this context primarily as the background for negotiation over purchasing those rights, whether it is firms that purchase them from consumers (in the form of more expansive self-help) or consumers who purchase them from firms (in the form of increased licensing and other fees, or the exercise of rights of fair use). There is essentially a fixed amount of wealth at stake. What we watch are the battles for wins and losses. ${ }^{104}$ The same may be said of arguments over internet taxation, ${ }^{105}$ jurisdiction, ${ }^{106}$ spam $^{107}$ and even privacy, publicity and defamation. ${ }^{108}$ Entitlements regarding all of these things are the internet's letters of transit.

What matters, then, are not the characters themselves and the roles they play, but the rise and fall of transaction costs. We watch the narrative to see how they develop and to see how they can be overcome. Ugarte murders two German couriers and delivers the letters to Rick for safekeeping, intending to sell them to Laszlo. Ugarte is a facilitator and a highly cynical one. Renault, knowing that the sale will take place at Rick's and wanting to keep Laszlo in Casablanca, makes a bet with Rick that Laszlo will not use the letters to escape. Having thus set the wheels of transaction costs in motion, Renault then arrests Ugarte, putting an end to the planned sale. Melodramatically, this merely sets the stage for a more involved contest for the letters. Metaphorically, the corrupt Renault has imposed a

102. See I. Trotter Hardy, The Proper Legal Regime for “Cyberspace,” 55 U. PITT. L. REV. 993, 1033-36 (1994).

103. See Specht v. Netscape Communications Corp., 306 F.3d 17, 28-32 (2nd Cir. 2002) (holding online agreement to arbitrate invalid because firm failed sufficiently to disclose terms of agreement to individuals downloading software).

104. See supra note 86 (“As Time Goes By").

105. See infra note 124 (Rick letting Renault win at roulette).

106. See supra note 76 ("Of all the gin joints in all the towns in all the world, she walks into mine!").

107. The melodrama of Casablanca is set in motion by the arrival of unwanted mail - the letters of transit.

108. Rick is in Casablanca, hiding. Laszlo comes to Casablanca, flaunting his identity. Eventually, Rick is forced first to disclose his true identity and then to disappear (again), providing an interesting commentary on changing approaches to values of identity, reputation, and free speech. 
transaction cost barrier that Rick (or some competitor) is challenged to overcome. (One could characterize this as government intermeddling, attempting to raise the cost of some activity by forbidding it.) ${ }^{109}$ With the letters hidden (by Rick) inside Sam's piano, Strasser and the Germans make a play for the letters, soliciting the French to turn Rick's nightclub upside down. ${ }^{110}$ This is a different sort of government intermeddling, perhaps an act of creative destruction of the market altogether. ${ }^{111}$ In either case, the transaction cost barrier to market control is too high even for them. ${ }^{112}$ Rick feints with the letters, using his relationship with Ilsa to secure safe passage for the lovers to the airport with Renault, only to doublecross Renault and deliver the letters to Laszlo in the end (A deal will be struck; the only question in the online world is the price). Rick ends the drama by solving the transaction cost difficulty, killing Strasser and sending Ilsa to Lisbon with Laszlo. ${ }^{113}$ Renault, recognizing that he has been played, yields to both the story and to the market paradigm. He has lost his bet with Rick. His departure with Rick for the free French garrison is either an exit from the market (al)together, or a bet that in the next market, he will get his money back.

\section{The Politics of Cyberspace}

The melodramatic metaphor is extended perhaps too far, as melodrama tends to be. As in the film itself, it must be tempered not only by the romantic plot line, but by the political theme as well. Will Rick recover his noble American spirit and join the fight for freedom? Will he join with Laszlo, who rouses the patrons of Rick's Café with an impromptu version of La Marseillaise (symbolizing a free France) in response to the Nazis' Die Wacht am Rhein? Will he sacrifice his love of Ilsa for the greater good? The film is hardly subtle on this point, ${ }^{114}$ but there are several themes at work, both in film and on the internet: the role of individual responsibility in the context of an oppressively ordered corporate or statist culture;

109. Some take this view of injunctions against file sharing services in the contest for copyright law entitlements. See Alfred C. Yen, A Preliminary Economic Analysis of Napster: Internet Technology, Copyright Liability, and the Possibility of Coasean Bargaining, 26 U. DAYTON L. REV. 247, 263-76 (2001). Similar arguments could be made with respect to regulation of online gambling and online pornography.

110. The Germans rely on the French, one transaction cost layered on top of another: "(Renault) Well, I told Strasser he wouldn't find the letters here. But I told my men to be especially destructive. You know how that impresses Germans." KoCH, supra note 75, at 125.

111. See Joseph A. Schumpeter, Capitalism, Socialism And Democracy 83-84 (3d ed. 1950) (describing innovation as part of a process of "creative destruction" of a market leader's position).

112. Again, this view of the Germans plays against type: "(Ferrari) (Rick's competitor in the nightclub business, played by Sidney Greenstreet) (speaking to Laszlo) We might as well be frank, M'sieur. It will take a miracle to get you out of Casablanca. And the Germans have outlawed miracles." KoCH, supra note 75 , at 124 .

113. Putting Ilsa and Laszlo on the plane to Lisbon is, in this odd sense, an efficient result. Had Rick boarded and left Laszlo behind, Laszlo, soon to be imprisoned, would represent a deadweight loss.

114. Its political bent is summed up in the following exchange: “(Ferrari) (responding to Rick's rejection of Ferrari's offer to go into business together on the black market) My dear Rick, when will you realize that, in this world today, isolationism is no longer a practical policy?" KoCH, supra note 75 , at 51 . 
the role of government and governance in the international order; and the role of both individual and group liberty. In the movie, Rick's role evolves along with his feelings for Ilsa and the barriers that both Germans and French put in his way. On the internet, we are far from a resolution of these issues, but one can see the outlines of analogous conflicts.

The Rick of the early part of the film is the United States in the early days of the internet, selfishly framing internet policy issues solely on its own terms. ${ }^{115} \mathrm{Or}$ perhaps, Rick is the modern iconoclast internet hacker, with no need for traditional government or regulation. ${ }^{116} \mathrm{We}$ see the emergence of both public and private governance mechanisms on the internet. The public is seen as national governments and public international organizations are now taking a more active role in defining the scope of internet regulation, and the United States is effectively required to participate (if reluctantly at times) in international regimes. ${ }^{117}$ Private governance systems are becoming more robust in the sense that formal private organizations have stepped up to address certain interests, ${ }^{118}$ in the sense that institutional interests operate effectively as governance structures ${ }^{119}$ and in the sense that private standard-setting bodies ${ }^{120}$ continue to exert a powerful influence on the underlying technical architecture of the internet. Overreaching at every level is at least theoretically cabined by national and supranational enforcement of unfair competition law ${ }^{121}$ and by norms and customs of online behavior and systems development. $^{122}$ Rick is redeemed at the end of the film, giving up Ilsa and

115. See Bruce A. Lehman, Working Group on Intellectual Prop. Rights, Intellectual PROPERTY AND THE NATIONAL INFORMATION INFRASTRUCTURE (Info. Infrastructure Task Force, 1995) (colloquially known as the "White Paper"), available at http://www.uspto.gov/web/offices/ com/doc/ipnii; Pamela Samuelson, The U.S. Digital Agenda at WIPO, 37 VA. J. INT'L L. 369, 379-80 (1997) (arguing that the White Paper formed the basis for an agenda regarding intellectual property rights on the internet that the United States pushed internationally).

116. Questioned informally by the Nazis, Rick confirms his "hacker" status: "(Strasser) What is your nationality? (Rick) I'm a drunkard. (Laughter) (Renault) That makes Rick a citizen of the world." $\mathrm{KoCH}$, supra note 75 , at 69.

117. See Graeme B. Dinwoodie, A New Copyright Order: Why National Courts Should Create Global Norms, 149 U. PA. L. REV. 469, 477-89 (2000); Joel R. Reidenberg, Yahoo and Democracy on the Internet, 42 JURIMETRICS J. 261, 275-78 (2002) (arguing that assertion of jurisdiction by French court over American internet firm can help promote democratic values); Berman, supra note 60, at 314317. Casablanca makes a strong case for American leadership in matters electronic: "(Strasser) You give him [Rick] credit for too much cleverness. My impression was that he's just another blundering American. (Renault) But we mustn't underestimate American blundering. I was with them when they blundered into Berlin in 1918." KoCH, supra note 75, at 104.

118. The leading example here would be ICANN, the Internet Corporation for Assigned Names and Numbers.

119. Examples here would be Internet Service Providers (ISPs) and On-line Service Providers (OSPs).

120. Such as the World Wide Web Consortium (W3C) and the Internet Engineering Task Force (IETF).

121. Such as cases in the United States and the European Union to enforce antitrust laws against Microsoft. See United States v. Microsoft Corp., 253 F.3d 34 (D.C. Cir. 2001).

122. It would stretch credulity to suggest that open source systems development is a sort of internet Resistance. But cf. Yochai Benkler, Coase's Penguin, or, Linux and the Nature of the Firm, 112 YALE L.J. 369 (2002) (exploring peer production structures as alternatives to hierarchical firms). But 
venturing off with Renault for the nearby free French garrison, ${ }^{123}$ implying metaphorically that individual liberty (Rick himself) and government regulation (Renault) can be reconciled and the public interest vindicated. Conflicts between liberty and community online are manageable once both sides recognize the greater good to be had from their cooperation. Individual liberty cannot be had without government; ${ }^{124}$ government cannot succeed without at least the symbolic consent of the governed. Strasser and the Germans become large rent-seeking institutions seeking to wrest governance of the resource from both the individual and represented public.

Perhaps this version is unduly optimistic, since the internet is far too young to have witnessed anything approaching the kind of climax that Casablanca implies, let alone a resolution. A different use of the political plot line of Casablanca contrasts cyberspace as the domain of the perfectly autonomous individual with cyberspace as the foundation for, and embodiment of, novel forms of community. The individuated cyberspace supplies the conditions for political empowerment and "cheap speech" by citizens with little need for access to traditional publishing intermediaries. ${ }^{125}$ It allows individuals to wrest control of cultural products - both physical control and cultural control—from their corporate producers. ${ }^{126}$ In theory, it allows the privatization of behavior that in the physical world would have significant negative external effects. ${ }^{127}$ From a commercial perspective, cyberspace and its technologies enable "mass customization," the holy grail of the price-discriminating merchant who wants to sell to every potential customer for no less than that customer is willing to pay.

Rick is all of these things: sole master of his political, cultural and commercial

both on the screen and in the world, norm-based governance requires trust: "Ugarte (asking Rick to hold the letters of transit): You know, Rick, I have many friends in Casablanca, but somehow, just because you despise me you are the only one I trust." KоCH, supra note 75, at 64. As we know, Ugarte's trust is misplaced, but Rick recovers his own sense of trust by the end of the film. $C f$. Benkler, Coase's Penguin, supra at 400-23 (describing networked communities for distributed production, such as the open source software community, as norm-based alternatives to the hierarchy of the firm).

123. Rick's parting words to Ilsa are classic film dialogue:

(Rick) But I've got a job to do too. Where I'm going you can't follow. What I've got to do you can't be any part of. Ilsa, I'm no good at being noble, but it doesn't take much to see that the problems of three little people don't amount to a hill of beans in this crazy world. Someday you'll understand that. Not now. Here's looking at you, kid.

$\mathrm{KoCH}$, supra note 75 , at 175.

124. Rick's success depends on Renault's cooperation: (Renault) Rick there are many exit visas sold in this café, but we know that you've never sold one. That is the reason we permit you to remain open. (Rick) I thought it was because we let you win at roulette. (Renault) Er, that is another reason." Id. at 62 .

125. See Eugene Volokh, Cheap Speech and What It Will Do, 104 YALE L.J. 1805, 1833-43 (1995).

126. See Raymond Shih $\mathrm{Ku}$, The Creative Destruction of Copyright: Napster and the New Economics of Digital Technology, 69 U. CHI. L. REV. 263, 300-22 (2002) (arguing that the economics of digital works of authorship suggest dramatic contraction of the scope of copyright protection for such works).

127. The internet can be "zoned." Whether it should be "zoned" is another matter. See supra note 7 and accompanying text (discussing use of "zoning" and other real place analogies to analyze cyberspace law problems). 
worlds, opening himself and his Café to all but a few, selectively closing off some because of history (Ilsa) or politics (a German banker who wishes to gamble in the back room). But individualism comes at a cost. The community inevitably makes demands on the individual, and the individual ultimately recognizes the value of the community. Free speech may cause harm. Control of the means (and ends) of cultural production creates responsibility for re-creating the cultural environment. Openness and security must be balanced. Privatization, even of "personal" activity, cannot isolate the individual forever. The Germans arrive. Their singing Die Wacht am Rhein in a display of German nationalism in the Café triggers a reaction (La Marseillaise, sung by the rest of the Café patrons), sanctioned by Rick. Accepting Ilsa back into his life, even briefly, leads Rick directly back to the community that he escaped earlier in his life. The ability to "customize" his commercial activity produces benefits, in that Rick can rig his roulette wheel to allow a refugee couple to win the cash they need to buy their way out of Casablanca (though to do so, he needs information about one member of the couple that many people would regard as private). It also imposes costs, since Rick can stay open only by allowing Renault access to the same illegality.

I leave to the critic or the lawyer the task of compiling a useful synthesis of these interwoven stories. I have substituted as much of my imagination for theirs as may be fair to do. Whatever the outcome of the various plots in cyberspace, and whatever their overall synthesis turns out to be, Casablanca makes clear that no one story can be resolved without interweaving it with the others. Cyberspace is not merely romance or commerce. It is both, with a significant dose of political philosophy thrown in.

\section{DISSOLVE TO: USING THE NARRATIVES}

A comprehensive and useful synthesis of the multiple plots and themes of cyberspace may be beyond the scope of my imagination, but a more limited synthesis is accessible, and it serves as an illustration not only of how this narrative approach may be useful in law, but also of how it is already (at least implicitly) part of the relevant legal discourse. I take as my reference the recent case of United States v. American Library Association, in which the Supreme Court considered the constitutionality of part of the federal Children's Internet Protection Act. ${ }^{128}$ The relevant portions of the statute conditioned local libraries' receipt of federal funds to support internet access on those libraries' installation of computer software that blocked patron access to obscene or pornographic images on websites. A district court enjoined enforcement of the statute, before it took effect, on the ground that libraries' use of such filtering software would necessarily violate the First Amendment as a content-based restriction on access to a public forum. ${ }^{129}$ Accordingly, conditioning receipt of federal internet access funds on use of the software violated Congress's authority under the Spending Clause. The decision

128. 123 S. Ct. 2297 (2003).

129. See American Library Ass'n, Inc. v. U.S., 201 F. Supp. 2d 401, 409-411 (E.D. Pa. 2002). 
was appealed directly to the Supreme Court.

The Court reversed by a vote of 6-3. The Court majority comprised three opinions in all. Two dissents were filed. The details of the justices' doctrinal analyses aside, most interesting for my purposes is that each of the opinions, save one, ${ }^{130}$ relied heavily on metaphorical and mostly narrative constructions of libraries, the internet, and behaviors within them. Chief Justice Rehnquist, writing for a plurality consisting of himself and Justices O'Connor, Scalia and Thomas, rejected the premise that access to the internet via a public library constitutes any sort of "public forum":

A public library does not acquire internet terminals in order to create a public forum for Web publishers to express themselves, any more than it collects books in order to provide a public forum for the authors of books to speak. It provides internet access . . . for the same reasons it offers other library resources: to facilitate research, learning, and recreational pursuits by furnishing materials of requisite and appropriate quality. . . A As Congress recognized, '[t]he internet is simply another method for making information available in a school or library.' S. Rep. No. 106-141, p. 7 (1999). It is 'no more than a technological extension of the book stack.'

Justice Breyer's concurring opinion similarly characterized the library's provision of internet access in narrative terms, though the opinion emphasized not the patron's process of "research, learning, and recreation pursuits" but instead the librarian's process of constructing the collection. His opinion viewed furnishing filtered internet access to websites as an extension of "the discretion necessary to create, maintain, or select a library's 'collection' (broadly defined to include all the information the library makes available)." 132 Justice Stevens, dissenting, took yet a third view of the narrative, explaining the steps that an adult patron would have to follow in order to request "unblocking" of a filtered site and concluding that the burden represented by those steps amounted to a significant (and unconstitutional) prior restraint on access to protected speech. ${ }^{133}$

The multiplicity of stories made possible by the intersection of libraries and cyberspace was most fully and interestingly explored, however, in the dissenting opinion of Justice Souter joined by Justice Ginsburg. Each of the three themes and

130. Justice Kennedy's concurrence suggested that an as-applied challenge to the statute, rather than a facial challenge, might better illustrate the extent to which library filtering interfered with legitimate adult interests in access to Constitutionally-protected material. See American Library, 123 S. Ct. at 2309-10 (Kennedy, J., concurring).

131. Id. at 2305 .

132. Id. at 2311 (Breyer, J., concurring).

133. Id. at 2315 (Stevens, J., dissenting):

Until a blocked site or group of sites is unblocked, a patron is unlikely to know what is being hidden and therefore whether there is any point in asking for the filter to be removed. It is as though the statute required a significant part of every library's reading materials to be kept in unmarked, locked rooms or cabinets, which could be opened only in response to specific requests. Some curious readers would in time obtain access to the hidden materials, but many would not. Inevitably, the interest of the authors of those works in reaching the widest possible Id. audience would be abridged. 
plots derived above for Casablanca and cyberspace are brought to bear on his conclusion that the statute was properly enjoined as unconstitutional. The dissent first considered the possibility that a library's decision to block or unblock a particular website is the legal equivalent of the library's decision to purchase a particular book. This is the melodrama of the book, which the opinion revealed as a Hitchcockian "macguffin," important not in itself but because of what it reveals about other interests: "Whereas traditional scarcity of money and space require a library to make choices about what to acquire . . blocking is the subject of a choice made after the money for internet access has been spent or committed." 134

The dissent's next step, from dismissing the "scarcity" rationale to characterizing internet filtering as "censorship," was to move from melodrama to romance. The opinion invoked the historic role of American public libraries and "freedom from censorship" as a defining characteristic of libraries' institutional mission: "Institutional history of public libraries in America discloses an evolution toward a general rule, now firmly rooted, that any adult entitled to use the library has access to any of its holdings." 135 Failure to extend that principle to cyberspace would effectively, but impermissibly, export public censorship. One thread remained, which is the political story, and the opinion used it to conclude its argument: "Quite simply, we can smell a rat when a library blocks material already in its control, just as we do when a library removes books from its shelves for reasons having nothing to do with wear and tear, obsolescence, or lack of demand. Content-based blocking and removal tell us something that mere absence from the shelves does not." ${ }^{136}$ Though not ultimately persuasive to a majority of the Court, the opinion demonstrates the utility for legal analysis of a complex interweaving of narratives, of cyberspace and, in this case, of libraries and literature.

\section{CUT TO: CONCLUSION}

In laying out my case for narrative understandings of cyberspace law, I have consciously integrated, to some degree, two distinct perspectives. On the one hand, and in arguing above that the very structure of cyberspace supplies the boundedness that permits its construction as a narrative, I offer an essentially internal, structural perspective. Cyberspace consists of an inherent but essentially novel story, defined dynamically by the limits imposed by computer software and hardware. ${ }^{137}$ Cyberspace, at this level, is inherently both technical and metaphorical. Cyberspace is the metaphor that describes the many technologies that comprise "the internet," and as a metaphor it is better understood as a narrative than as a "thing" in how it describes connections between and relationships among individuals, entities, concepts and technologies. On the other hand, and in offering the stories, characters and themes of Casablanca as a valuable example of a

134. Id. at 2321 (Souter, J., dissenting).

135. Id. at 2322 (Souter, J., dissenting).

136. Id. at 2324 (Souter, J., dissenting).

137. See supra notes 21-60 and accompanying text. 
narratival reading of cyberspace, I offer the external perspective of the reader, creating and interpreting "cyberspace" by mediating online experience via the patterns supplied by the classic plots, characters and themes combined in the film. ${ }^{138}$ My argument is certainly open to critique on the ground that I have offered both views and not distinguished or chosen clearly between them.

I confess that I have not done so, but I suggest that such a clean distinction is not, in the end, feasible. The interpretive exercise that constitutes the "external" understanding of cyberspace-as-narrative is essential to the construct that supplies an "internal" understanding of cyberspace-as-narrative. The second perspective defines the conditions that make different features of the second perspective relevant; in effect, we construct the story of cyberspace via the stories through which we understand cyberspace. Here is the recursive character of cyberspace to which I referred above. ${ }^{139}$ The romantic story of cyberspace, the search for "openness" at different technical levels of the internet, leads to legal rules promoting (or discouraging) openness and ultimately to technologies that reinforce that openness. The melodrama of cyberspace, the search for markets implicit in the technology of the internet, leads to rules reinforcing (or disrupting) markets and eventually to technologies that do likewise. The political story of cyberspace, the conflict between public and private interests embedded in the technology, leads to rules that reify (or reconstruct) those interests, and then to technologies that confirm the rules. The narrative metaphor is itself recursive. At the end of Casablanca, Rick Blaine himself walks away from Casablanca to join the Resistance, to become, in effect, a Victor Laszlo to replace the Laszlo now flying to America. The unproduced sequel to Casablanca is a version of Casablanca itself.

The apparent implausibility of adopting the Casablanca narrative is thus more than merely rebutted by the equal implausibility of some, if not all, of narrative's metaphorical predecessors. Narrative is clearly superior, in at least two key respects. In the end cyberspace, like any great and enduring story, owes its resonance to the ongoing emotional and intellectual investments of its interpreters as much as to the efforts of its creators. An enduring metaphor of cyberspace needs to account, as I have done indirectly, for the blurring of object and subject, audience and participant, and player and viewer, which characterizes the medium. ${ }^{140}$ A metaphor of place adopts the static distinctions of "place," distinctions between the place and the person and between one place and another. A great story invites new reconstructions. It welcomes that blurring, and it welcomes change. The liberty I have taken in characterizing "cyberspace" as Casablanca is a liberty granted by both the story and the medium. My deconstructing and reconstructing different plots and attributes is an implicit argument that this is a permissible use of the film, that Casablanca belongs as

138. See supra notes 61-127 and accompanying text.

139. See supra note 56 and accompanying text. See Richard J. Ross, Communications Revolutions and the Legal Culture: An Elusive Relationship, 27 LAW \& SOC. INQUIRY 638, 648-49 (2002) (discussing Nazareth A.M. Pantaloni, III, Legal Databases, Legal Epistemology, and the Legal Order, 86 LAW LIB. J. 679 (1994)).

140. See MitCHELL, supra note 5. 
much to me as it does to Bogart, or to its director, Michael Curtiz. Rick and Ilsa matter not. They are archetypes, in which generations of film-goers have recognized universal experience. ${ }^{141}$ Cyberspace, for its part, "belongs" in a sense to me, as well as to all others who build it and use it. That point should be emphasized and extended. Cyberspace is defined not only by millions of individual experiences, but also by the experiences of social networks and of institutions. Wireless networks are "part" of the internet and, therefore, of cyberspace not merely because protocols permit the interchange of appropriate digitized information. They are part of cyberspace, because some significant population of users has elected to integrate wireless networking technology into their lives. How cyberspace is defined for regulatory purposes depends as much on these understandings as it depends on the understandings of computer technologists. Each depends on the other.

Other films, other works, and other stories may, in the end, serve as well as or better than Casablanca in accounting for law in cyberspace. ${ }^{142}$ Any other story of cyberspace needs to have the flexibility to accommodate the many demands of its subject and its overlapping themes and plots. My use of Casablanca itself shows that cyberspace is no simple story, and there are few stories with massive popular appeal that capture the multiplicity represented in both this film and in cyberspace. But the moral of the story (of this Article) is this: the computers of the internet are out there, but we construct cyberspace. For that reason, and celluloid aside, the notion of cyberspace-as-narrative deserves an extended stay in the pantheon of metaphorical conceptions of cyberspace. Physicalized metaphors are appealing for now, and they are embedded in our language. They may not endure as technology and experience evolve. Even if they do endure, however, they may prove more limiting than illuminating. That risk exists with any metaphor. A narrative framework, at least, contains in itself a design for adaptation and evolution. It may eventually provide a better understanding of how to approach the legal and policy questions posed by this new technology.

141. See Eco, supra note 74, at 11:

When all the archetypes burst in shamelessly, we reach Homeric depths. Two cliches make us laugh, but a hundred cliches move us because we sense dimly that the cliches are talking among themselves and celebrating a reunion. Just as extreme pain meets sensual pleasure, and extreme perversion borders on mystical energy, so does extreme banality allow us to catch a glimpse of the sublime. Nobody would have been able to achieve such a result intentionally. Nature has Id. spoken here in place of men.

142. Not only is Casablanca a classic of Western film, it is also a classic of a now (mostly) outmoded cultural ideology that celebrates the reserved, but heroic, lone white male as the master (author) of his fate. See Robin West, The Literary Lawyer, 27 PAC. L.J. 1187, 1196-98, 1206-11 (1996) (noting the critique that the literary canon is exclusionary, elitist and "textual"). Then again, maybe little of that matters, at least here, and at least with this source. See Peter Jaszi, Who Cares Who Wrote "Shakespeare"?, 37 AM. U. L. REv. 617, 622-24 (1988) (noting that the value of Shakespeare for contemporary society lies in the openness of the texts to interpretation). 